\title{
Gene expression and characterization of 2-keto-3-deoxy-gluconate kinase, a key enzyme in the modified Entner-Doudoroff pathway of Serratia marcescens KCTC 2172
}

\author{
Yong-Seok Lee \\ Department of Biotechnology \\ Faculty of Natural Resources and Life Science \\ Dong-A University \\ Busan, 604-714, Korea \\ In-Hye Park \\ Department of Biotechnology \\ Faculty of Natural Resources and Life Science \\ Dong-A University \\ Busan, 604-714, Korea \\ Ju-Soon Yoo \\ Department of Food Science and Nutrition \\ Dong-Ju College \\ Busan, Korea \\ Hae-Sun Kim \\ Department of Biotechnology \\ Dong-A University \\ Busan, 604-714, Korea \\ Soo-Yeol Chung \\ Department of Food Science \\ Dong-Ju College \\ Busan, 604-715, Korea \\ Muni Ramanna GariSubhosh Chandra \\ Department of Biotechnology \\ Dong-A University \\ Busan, 604-714, Korea \\ Yong-Lark Choi* \\ Department of Biotechnology \\ Faculty of Natural Resources and Life Science \\ Dong-A University 840, Hadan-dong \\ Saha-gu, Busan, 604-714, Korea \\ Tel: 82512006536 \\ Fax: 82512006536 \\ E-mail: ylchoi@dau.ac.kr
}

Financial support: Research fund of Dong-A University.

Keywords: 2-keto-3-deoxygluconate kinase, carbohydrate kinase, purification, Serratia marcescens KCTC 2172.

Abbreviations: GST: Glutatione S-transferase

KDG: 2-keto-3-deoxygluconate

KDGK: 2-keto-3-deoxy-gluconate kinase

KDPG: 2-keto-3-deoxy-6-phophogluconate

KG: 2-ketogluconate

mms: maltose metabolism stimulation

ORF: open reading frames

SDS-PAGE: sodium dodecyl sulphate-spolyacrylamide gel electrophoresis

We cloned 2-keto-3-deoxy-gluconate kinase (KDGK), which catalyzes the phosphorylation of 2-keto-3-

*Corresponding author 
deoxygluconate (KDG) to 2-keto-3-deoxy-6phophogluconate (KDPG) from Serratia marcescens KCTC 2172. The nucleotide sequence revealed a single open reading frame containing 1,208 bp and encoding for 309 amino acids, with a molecular weight of 33,993 Da. The enzyme was purified via GST affinity chromatography. The putative KdgT binding site was detected upstream of the initial codon. The KDG kinase utilized 2-ketogluconate (KG) and KDG as substrates. The optimal temperature and pH for KDGK activity were $50^{\circ} \mathrm{C}$ and 8.0 , respectively.

Serratia is gram-negative bacteria, classified in the large family of Enterobacteriaceae. Serratia can be distinguished from other genera by its production of three special enzymes DNase, lipase and gelatinase. Another characteristic feature of the Serratia among the family Enterobacteriaceae, in the tribe Klebsiella has been widely considered a red-pigmented organism. Serratia, like other Enterobacteria, grow well on ordinary media under anaerobic and aerobic conditions. They grow well on synthetic media using various carbon sources (Giri et al. 2004). Serratia marcescens is an enteric bacterium closely related to Escherichia coli and secretes several enzymes through the membrane into culture broth, including nucleases, lipases, proteases, chitinases (Gal et al. 1998), coenzyme A transferase, cyclic AMP receptor protein, acetoacetyl coenzyme A transferase (Yoo et al. 2000; Yoo et al. 2001), maltose metabolism stimulation, polyphosphate kinase and exopolyphosphatase (Lee et al. 2000; Lee et al. 2006).

2-Keto-3-deoxygluconate kinase (KDGK), which catalyzes the phosphorylation of 2-keto-3-deoxy-gluconate (KDG), plays a role in the carbohydrate metabolism of Clostridia and some of the aerobic bacteria (Ohshima et al. 2007). KDG is an important intermediate of the degradation of extracellular pectin, which is processed and incorporated into cells, and then converted into KDG in Erwinia chrysanthemi (Hugouvieux-Cotte-Pattat et al. 1996). In $E$. coli (Mandrand-Berthelot et al. 1984) and E. chrysanthemi, extracellular KDG is also utilized by assimilation via the KDG transporter. KDG is also reported to be produced from D-glucosaminate by D-glucosaminate dehydratase in Pseudomonas fluorescens (Iwamoto and Imanaga, 1991).

The pathways of pectin and galacturonate catabolism in bacteria converge to form a common intermediate, KDG, which is phosphorylated by KDG kinase. The KDGK product is the last step of pectin catabolism that is identified at the molecular level in E. chrysanthemi. In this organism, breakdown of pectic polymers involves various types of pectinolytic enzymes. This cleavage gives two kinds of monomeric sugar: 5-keto-4-deoxyuronate (KDU) and Dgalacturonate. These monomers are catabolized by two independent pathways converging through a common intermediate: KDG. The ketodeoxyuronate catabolic pathway is composed of successive isomerization and oxidoreduction steps catalyzed by the kduI and kduD gene products (Condemine et al. 1986; Condemine and RobertBaudouy, 1991). The galacturonate catabolic pathway consists of three enzymes encoded by the operon uxaCBA. Similarly, hexuronate, glucuronate, can be degraded by three parallel steps catalyzed by the uxaC, uxuB, and uxuA gene products (Hugouvieux-Cotte-Pattat and RobertBaudouy, 1987). The common catabolic product KDG, is then phosphorylated by the KDGK, yielding 2-keto-3deoxy-6-phophogluconate (KDPG), which is cleaved by the KDG aldolase gene product to give intermediates of the general cellular metabolism (Hugouvieux-Cotte-Pattat and Robert-Baudouy, 1985). In order to find out whether the increased expression of KDGK under the direction of a strong promoter such as tac promoter is necessary and genes for the putative $S$. marcescens 2-keto-3deoxygluconate kinase are introduced into a bacterial expression vector pKK223-4. The aim of the present study was to express pKKDGKin Escherichia coli and determine the enzymological properties of the purified product to obtain a better understanding of the modified ED pathway in Serratia marcescens KCTC 2172.

\section{MATERIALS AND METHODS}

\section{Cloning and expression of the $k d g K$ gene}

In a previous study (Yoo et al. 2000; Yoo et al. 2001), we constructed several clones from a genome library of Serratia marcescens KCTC 2172. In this study, pCKB17, one of the clones from the genome library, was analyzed in more detail. The nucleotide sequence of pCKB17 was determined, and a restriction map of the cloned DNA fragment and several recombinant subclones was constructed (Figure 1). The open reading frame of the cloned $k d g K$ gene was amplified via PCR with the 5' and 3' primers: 5'-AGCCCGGGCTTATTGA-CGATGACTATC3' and 5'-CATAATCAATAAGGCGGCGGCGAAGCTTCC-3`, harboring the SmaI and HindIII restriction enzyme sites. pCKB17 was utilized as a template DNA. Following digestion with SmaI and HindIII, this PCR product was cloned into pKK223-4 and digested with the corresponding enzymes for the construction of pKKDGK. The culture was cultivated in M9 minimal medium containing $0.1 \%$ glucose and casamino acids (Le et al. 2006). E. coli BL21 (DE3) harboring pKKDGK was induced for over-expression with $0.1 \mathrm{mM}$ isopropyl- $\beta$-Dthiogalactopyranoside (IPTG) at the mid-exponential growth phase, then incubated for $3 \mathrm{hrs}$ at $37^{\circ} \mathrm{C}$.

\section{Purification of recombinant KDGK}

Cells were harvested via centrifugation (6000 rpm for 15 min at $4^{\circ} \mathrm{C}$ ), washed with buffer $1 \times$ PBS buffer (Diluted 10 $x$ PBS, $1.4 \mathrm{M} \mathrm{NaCl}, 27 \mathrm{mM} \mathrm{KCl}, 100 \mathrm{mM} \mathrm{Na}_{2} \mathrm{HPO}_{4}$ and 18

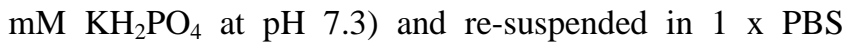
buffer. The cells were disrupted by sonication and the supernatant was acquired through 30 min of centrifugation at $13000 \mathrm{rpm}$ at $4^{\circ} \mathrm{C}$. The sonicated solution was then loaded onto a GSTrap FF column (Amersham Pharmacia 
Table 1. Purification of the recombinant KDGK.

\begin{tabular}{|c|c|c|c|c|c|}
\hline Steps & $\begin{array}{c}\text { Total protein } \\
\text { (mg) }\end{array}$ & $\begin{array}{c}\text { Total activity } \\
\text { (U) }\end{array}$ & $\begin{array}{c}\text { Specific } \\
\text { activity } \\
\text { (U/mg) }\end{array}$ & $\begin{array}{c}\text { Yield } \\
\text { (\%) }\end{array}$ & $\begin{array}{c}\text { Purification } \\
\text { (fold) }\end{array}$ \\
\hline Crude extract & 168 & 203 & 0.82 & 100 & 1 \\
\hline $\begin{array}{c}\text { GST affinity } \\
\text { chromatography }\end{array}$ & 1.9 & 24 & 12.6 & 11.8 & 15 \\
\hline
\end{tabular}

Biotech), equilibrated with $1 \times$ PBS, and eluted with 10 $\mathrm{mM}$ reduced glutathione in $50 \mathrm{mM}$ Tris- $\mathrm{HCl}(\mathrm{pH} 7.5)$ at a flow rate of $1 \mathrm{ml} / \mathrm{min}$. The eluted fractions were dialyzed overnight against PreScission cleavage buffer (50 mM Tris$\mathrm{HCl}, 150 \mathrm{mM} \mathrm{NaCl}, 1 \mathrm{mM}$ EDTA and $1 \mathrm{mM}$ dichlorodiphenyltrichloroethane at $\mathrm{pH}$ 7.0) and concentrated using Amicon Ultra-4 strips (Millipore, Bedford, MA, USA). The purified fusion protein was then digested with PreScission protease for 12 hrs at $5^{\circ} \mathrm{C}$ to remove the GST region, and then the digested fusion protein was loaded onto a GSTrap FF column chromatography as described above. The unbound fraction was collected and employed as the purified enzyme.

\section{Enzyme assay}

The enzyme coupling assay for KDGK was conducted by the method described by Ohshima et al. (2007). The standard reaction system consisted of $50 \mathrm{mM}$ Tris- $\mathrm{HCl}(\mathrm{pH}$ 8.5), $10 \mathrm{mM} \mathrm{KDG}, 10 \mathrm{mM}$ glucose, $2.5 \mathrm{mM}$ ATP, $10 \mathrm{mM}$ $\mathrm{MgCl}_{2}, \quad 6 \mathrm{H}_{2} \mathrm{O}, 1 \mathrm{U}$ of yeast glucose-6-phosphate dehydrogenase, $1 \mathrm{U}$ of ADP-glucokinase, $1 \mathrm{mM}$ NADP, and the enzyme in a total volume of $1.0 \mathrm{ml}$. The reaction was initiated via the addition of ATP, and an increase of absorbance at $340 \mathrm{~nm}$, which is reflective of NADPH formation, followed at $50^{\circ} \mathrm{C}$. One unit of enzyme activity was defined as the amount of enzyme required to generate 1 $\mu$ mol of ADP per min under the standard assay conditions, and the specific activity was expressed in U/mg of protein. Protein concentrations were determined using the method of Bradford (1976), with bovine serum albumin as the standard. ADP-dependent glucokinase was acquired from Asahi Pharma, Tokyo.

\section{Polyacrylamide gel electrophoresis}

Sodium dodecyl sulfate-polyacrylamide gel electrophoresis (SDS-PAGE) was conducted by the method of Laemmli (1970). After SDS-PAGE, the gel was stained with $0.05 \%$ Coomassie brilliant blue R-250.

\section{Effect of temperature and $\mathrm{pH}$ on enzyme activity}

The effects of temperature on enzyme activity were determined by the incubation of the reaction mixtures at temperatures ranging from 30 to $80^{\circ} \mathrm{C}$ in $50 \mathrm{mM}$ Tris- $\mathrm{HCl}$ at $\mathrm{pH}$ 8.5. In order to determine the optimal $\mathrm{pH}$ for the enzyme activity, standard assay mixtures in the following buffers were utilized: $20 \mathrm{mM}$ citrate buffer (pH 3.0-6.0), 20 $\mathrm{mM}$ sodium phosphate buffer (pH 6.0-7.6), $20 \mathrm{mM}$ Tris$\mathrm{HCl}(\mathrm{pH}$ 7.5-9.0) and glycine-NaOH buffer ( $\mathrm{pH} 10.0)$.

\section{RESULTS}

\section{Cloning and expression of the kdgK gene}

Sequence analysis showed that the presence of two open reading frames (ORFs), in which one ORF is maltose metabolism stimulation (mms) (Lee et al. 2000) and the other is a 2-keto-3-deoxygluconate kinase gene. Both showed opposite transcriptional directions. The KDGK ORF began with the initiation codon ATG at position 235 bp, located 10 bases downstream of the putative ribosomal binding site (AGGG), and the ending codon with the termination codon TAA at position 1160. The ATG codon was selected as the translation initiation site because its location was close to the possible ribosome binding site, 5'AGGG-3'. The deduced KDGK amino acid sequence corresponds to a protein of 309 amino acids with a molecular weight of 33,993 Da. The putative RNA polymerase binding site evidenced the following homology to the classical consensus: 4 of 6 nt (TTGGCC) for the -35 region at position 121 and 4 of $6 \mathrm{nt}$ (TAAAAC) for the -10 region at 126, with a spacing of $19 \mathrm{nt}$. At the 3 ' end of the KDGK gene and surrounding the KDGK translational stop, there is a GC-rich imperfect inverted repeat (GCGGCGGCG-9nt-CGCCGCCC) followed by a run of A-T residues (TAATCAATAA). This sequence is typical for rho-independent transcription termination sites (Figure 2) (Von Hippel et al. 1984).

\section{Alignment of the KDGK operator with the consensus of the KdgR binding site}

Most of the KDGK genes regulated by the KdgR repressor harbor a typical KdgR-binding site (Reverchon et al. 1989). The consensus sequence of the KdgR binding site was detected at the 5'-untranslated end of KDGK. Sequence matching with the consensus 5'-AATAAAAC-xxCGTTTCA-3' of the KdgR binding site (Hugoumiex-Cotte- 
Pattat et al. 1994) showed a $12 / 15$ bp match between the consensus KdgR binding sequence and the $S$. marcescens binding site, 5'-ATTAAAAC-AC-TGTTTAA-3' (Figure $3)$. This putative KdgR binding region partially overlaps the -10 element of the putative promoter region (Figure 2). This demonstrates that KdgR represses RNA polymerase for overlapping binding sites, thereby inhibiting transcriptional initiation.

\section{Amino acid sequence similarities between KDG kinase and other proteins}

Comparison of the KDG kinase with the NCBI databank revealed significant homology with an approximate $70 \%$ identity with the KDG kinase of Yersinia pseudotuberculosis, $69 \%$ identity with Erwinia chrysanthemi, and 68\% identity with Salmonella enterica. These enzymes belong to the PfkB family among carbohydrate kinase families (Wu et al. 1991) (Figure 4).

\section{Purification of the recombinant enzyme}

The purification procedure is summarized in Table 1. E. coli cells harboring pKKDGK were expressed and evidenced increased enzyme activity after induction, but not the vector plasmid. The expressed enzyme was purified approximately 15 fold with an $11.8 \%$ recovery via GST affinity chromatography (Table 1). Subjecting the purified enzyme to SDS-PAGE generated a single protein band corresponding to a molecular mass of $34 \mathrm{kDa}$ (Figure 5). Approximately $1.9 \mathrm{mg}$ of the purified enzyme was acquired and the specific activity of the final preparation was estimated to be $12.6 \mathrm{U} / \mathrm{mg}$ (Table 1 ). The enzyme reaction was significant for both the substrates, 2-keto-gluconate (KG) and KDG. However, KDG proved to be approximately nine times (8.3) higher than KG (0.95) with regard to kinase specific activity.

\section{Effect of temperature and pH on KDG kinase activity}

When we evaluated the effects of temperature on KDGK activity, we detected maximum activity at $50^{\circ} \mathrm{C}$, and the activity declined suddenly at temperatures above $50^{\circ} \mathrm{C}$ such that the activity at $80^{\circ} \mathrm{C}$ was only approximately $20 \%$ that observed at $50^{\circ} \mathrm{C}$ (Figure 6). When we determined the effects of $\mathrm{pH}$ on KDGK activity, we noted that the maximum activity was observed at $\mathrm{pH}$ 8.0, the activity declined slightly at $\mathrm{pH}$ values above 8.0 , and very slight activity was noted at $\mathrm{pH} 5.0$ and 6.0 (Figure 7).

\section{DISCUSSION}

The KDG kinase is the key enzyme in the semiphosphorylative ED pathway. This enzyme is a member of the ribokinase (PfkB) enzyme family, which is composed of prokaryotic sequences related to ribokinase, including enzymes such as fructokinases, the minor 6phosphofructokinase of E. coli, 1-phosphofructokinase, and archaeal ADP-dependent glucokinases and phosphofructokinases (Ito et al. 2001). Thus far, the KDGK gene was cloned, expressed, and characterized in E. coli, Erwinia chrysanthemi, Sulfolobus tokodaii, and Sulfolobus solfataricus in the modified Entner-Doudoroff Pathway (Cynkin and Ashwell, 1960; Hugouvieux-Cotte-Pattat et al. 1994; Kim and Lee, 2006; Ohshima et al. 2007). The PfkB kinases are generally composed of 310 to 430 amino acid residues (Hugouvieux-Cotte-Pattat et al. 1994) and are distinguished by three domains ( $\mathrm{N}$ terminal, middle, $\mathrm{C}$ terminal) (Henikoff and Henikoff, 1991). There are regions corresponding to the two signature patterns of carbohydrate kinases of the PfkB family. Consensus pattern 1 is $[A, G]-$ G-[x]-[G,P]-x-N-x-[S,T,A]-6x-[G,S]-9x-G and consensus pattern 2 is [D,N,S]-[P,T,S]-X-[S,A,G]-[S,A,G]-G-D-3X$[\mathrm{A}, \mathrm{G}]-[\mathrm{A}, \mathrm{G}]-[\mathrm{L}, \mathrm{I}, \mathrm{V}, \mathrm{M}] \quad-[\mathrm{L}, \mathrm{I}, \mathrm{V}, \mathrm{M}, \mathrm{S}, \mathrm{T}, \mathrm{A}]$ among the consensus patterns of the PfkB family. Consensus pattern 2 was shown to be involved in ATP binding ability (Aulkemeyer et al. 1991). KDGK evidences significant homology, and approximately $70 \%$ identity with the KDG kinase of Yersinia pseudotuberculosis.

The apparent molecular weight of the KDGK from Serratia marcescens KCTC 2172 was $34 \mathrm{kDa}$, similar to that from Sulfolobus tokodaii (Ohshima et al. 2007); a value of 35 $\mathrm{kDa}$ was detected from Sulfolobus solfataricus (Kim and Lee, 2006) and $160 \mathrm{kDa}$ from Thermus thermophiles (Ohshima et al. 2004) In the hyperthermophile, Sulfolobus tokodaii, the maximum activity of the enzyme was observed at $80^{\circ} \mathrm{C}$, the activity declined rapidly at temperatures above $80^{\circ} \mathrm{C}$ (Ohshima et al. 2007). The maximum enzyme activity was noted at between 70 and $80^{\circ} \mathrm{C}$ and the optimal $\mathrm{pH}$ between 7.0 and 8.0 in $S$. sulfatoricus KDGK (Kim and Lee, 2006). In the present study, KDG kinase activity evidenced optimal activity at a temperature of $50^{\circ} \mathrm{C}$ and a $\mathrm{pH}$ value of 8.0 . In this study, we successfully expressed the Serratia marcescens KCTC 2172 gene and identified a product that evidenced KDGK activity.

\section{ACKNOWLEDGEMENTS}

We thank Asahi Kasei Pharma in Tokyo and Professor Toshihisa Ohshima for the generous gift of ADP-dependent glucokinase.

\section{REFERENCES}

AULKEMEYER, P.; EBNER, R.; HEILENMANN, G.; JAHREIS, K.; SCHMID, K.; WRIEDEN, S. and LENGELER, J.W. Molecular analysis of two fructokinases involved in sucrose metabolism in enteric bacteria. Molecular Microbiology, December 1991, vol. 5, no. 12, p. 2913-2922.

BRADFORD, Marion M. A rapid and sensitive method for the quantitation of microgram quantities of protein utilizing the principle of protein-dye binding. Analytical Biochemistry, May 1976, vol. 72, no. 1-2, p. 248-254. 
CONDEMINE, Guy; HUGOUVIEUX-COTTE-PATTAT, Nicole and ROBERT-BAUDOUY, Janine. Isolation of Erwinia chrysanthemi KduD mutants altered in pectin degradation. Journal of Bacteriology, March 1986, vol. 165, no. 3, p. 937-941.

CONDEMINE, Guy and ROBERT-BAUDOUY, Janine. Analysis of an Erwinia chrysanthemi gene cluster involved in pectin degradation. Molecular Microbiology, September 1991, vol. 5, no. 9, p. 2191-2202.

CYNKIN, Morris A. and ASHWELL, Gilbert. Uronic acid metabolism in bacteria. IV. Purification and properties of 2keto-3-deoxy-D-gluconokinase in Escherichia coli. Journal of Biological Chemistry, June 1960, vol. 235, no. 6, p. 1576-1579.

GAL, Sang Wan; CHOI, Ji Young; KIM, Cha Young; CHEONG, Young Hwa.; CHOI, Young Ju; LEE, Sang Yeol; BAHK, Jeong Dong and CHO, Moo Je. Cloning of the 52-kDa chitinase gene from Serratia marcescens KCTC2172 and its proteolytic cleavage into an active 35kDa enzyme. FEMS Microbiology Letters, March 1998, vol. 160, no. 1, p. 151-158.

GIRI, Anuradha V.; ANANDKUMAR, Nandini; MUTHUKUMARAN, Geetha and PENNATHUR, Gautam. A novel medium for the enhanced cell growth and production of prodigiosin from Serratia marcescens isolated from soil. BMC Microbiology, March 2004, vol. 4, p. 11.

HALL, Tom A. BioEdit: a user-friendly biological sequence alignment editor and analysis program for Windows 95/98/NT. Nucleic Acids Symposium Series,1999, vol. 41, p. 765-768.

HUGOUVIEUX-COTTE-PATTAT, Nicole and ROBERTBAUDOUY, Janine. Isolation of $k d g K-l a c$ and $k d g A-l a c$ gene fusion in the phytopathogenic bacterium Erwinia chrysanthemi. Microbiology, May 1985, vol. 131, no. 5, p. 1205-1211.

HUGOUVIEUX-COTTE-PATTAT, Nicole and ROBERTBAUDOUY, Janine. Hexauronate catabolism in Erwinia chrysanthemi. Journal of Bacteriology, March 1987, vol. 169, no. 3, p. 1223-1231.

HUGOUVIEUX-COTTE-PATTAT, Nicole and ROBERTBAUDOUY, Janine. Isolation of Erwinia chrysanthemi mutantsaltered in pectinolytic enzyme production. Molecular Microbiology, November 1989, vol. 3, no. 11, p. 1587-1597.

HUGOUVIEUX-COTTE-PATTAT, Nicole; NASSER, William and ROBERT-BAUDOUY, Janine. Molecular characterization of the Erwinia chrysanthemi $k d g K$ gene involved in pectin degradation. Journal of Bacteriology, April 1994, vol. 176, no. 8, p. 2386-2392.
HUGOUVIEUX-COTTE-PATTAT, Nicole;

CONDEMINE, Guy; NASSER, William and REVERCHON, Sylvie. Regulation of pectinolysis in Erwinia chrysanthemi. Annual Review of Microbiology, 1996, vol. 50, p. 213-257.

ITO, Sohei; FUSHINOBU, Shinya; YOSHIOKA, Issei; KOGA, Shinji; MATSUZAWA, Hiroshi and WAKAGI, Takayoshi. Structural basis for the ADP-specificity of a novel glucokinase from a hyperthermophilic archaeon. Structure, March 2001, vol. 9, no. 3, p. 205-214.

IWAMOTO, Ryoko and IMANAGA, Yujiro. Direct evidence of the Entner-Doudoroff pathway operating in the metabolism of D-glucosamine in bacteria. Journal of Biochemistry, January 1991, vol. 109, no. 1, p. 66-69.

KIM, Seonghun and LEE, Sun Bok. Characterization of Sulfolobus solfataricus 2-keto-3-deoxy-D-gluconate kinase in the modified Entner-Doudoroff pathway. Bioscience, Biotechnology and Biochemistry, 2006, vol. 70, no. 6, p. 1308-1316.

LAEMMLI, U.K. Cleavage of structural proteins during the assembly of the head of bacteriophage T4. Nature, August 1970, vol. 227, no. 5259, p. 680-685.

LE, Thuc T.; GUET, Calin C. and CLUZEL, Philippe. Protein expression enhancement in efflux-deleted mutant bacteria. Protein Expression and Purification, July 2006, vol. 48 , no. 1 , p. $28-31$.

LEE, S.J.; SONG, O.R.; CHUNG, S.Y.; LEE, Y.C. and CHOI, Y.L. Characterization of polyphosphate kinase gene in Serratia marcescens. Journal of Life Science, 2000, vol.10, p. 397-402.

LEE, S.J.; YOO, J.S.; KIM, H.S.; LEE, S.C.; CHUNG, S.Y. and CHOI, Y.L. Analysis and cloning of the gene involved in activation of maltose metabolism in Serratia marcescens. Korean Journal of Applied Microbiology and Biotechnology, 2000, vol. 28, no. 1, p. 21-25.

LEE, Seung-Jin; LEE, Yong-Seok; LEE, Young-Choon and CHOI, Yong-Lark. Molecular characterization of polyphosphate (polyP) operon from Serratia marcescens. Journal of Basic Microbiology, April 2006, vol. 46, no. 2, p. 108-115.

MANDRAND-BERTHELOT, Marie-Andree; RITZENTHALER, Paul and MATA-GILSINGER, Mireille. Construction and expression of hybrid plasmids containing the structural gene of the Escherichia coli K-12 3-deoxy-2-oxo-D-gluconate transport system. Journal of Bacteriology, November 1984, vol. 160, no. 2, p. 600-606.

NASSER, William; REVERCHON, Sylvie; CONDEMINE, Guy and ROBERT-BAUDOUY, Janine. Specific interactions of Erwinia chrysanthemi KdgR repressor with different operators of genes involved in 
pectinolysis. Journal of Molecular Biology, February 1994, vol. 236, no. 2, p. 427-440.

OHSHIMA, N.; INAGAKI, E.; YASUIKE, K.; TAKIO, K.; TAHIROV, T.H. Structure of Thermus thermophilus2keto-3-deoxygluconate kinase: evidence for recognition of an open chain substrate, Journal of Molecular Biology, 2004, vol. 340, p. 477-489.

OHSHIMA, Toshihisa; KAWAKAMI, Ryushi; KANAI, Yuichiro; GODA, Shuichiro and SAKURABA, Haruhiko. Gene expression and characterization of 2-keto-3deoxygluconate kinase, a key enzyme in the modified Entner-Doudoroff pathway of the aerobic and acidophilic hyperthermophile Sulfolobus tokodaii. Protein Expression and Purification, July 2007, vol. 54, no. 1, p. 73-78.

REVERCHON, Sylvie; HUANG, Yue; BOURSON, Claude and ROBERT-BAUDOUY, Janine. Nucleotide sequences of Erwinia chrysanthemi ogl and pelE genes negatively regulated by the $k d g R$ product. Gene, December 1989, vol.85, no. 1, p. 125-134.

VON HIPPEL, Peter H.; BEAR, David G.; MORGAN, William D. and MCSWIGGEN, James A. Protein-nucleic acid interaction in transcription: a molecular analysis. Annual Review of Biochemistry, July 1984, vol. 53, p. 389446.

WU, L.F.; REIZER, A.; REIZER, J.; CAI, B.; TOMICH, J.M. and SAIER, M.H. Nucleotide sequence of the Rhodobacter capsulatus fruK gene, which encodes fructose-1-phosphate kinase: evidence for a kinase superfamily including both phosphofructokinases of Escherichia coli. Journal of Bacteriology, May 1991, vol. 173, no. 10, p. 3117-3127.

YOO, Ju-Soon; KIM, Hae-Sun; CHUNG, Soo-Yeol and CHOI, Yong-Lark. Molecular characterization of crp, the cyclic AMP receptor protein gene of Serratia marcescens KTCC 2172. Journal of Microbiology and Biotechnology, 2000, vol. 10, no. 5, p. 670-676.

YOO, Ju Soon; KIM, Hae Sun; LEE, Young Choon; CHUNG, Soo Yeol and CHOI, Yong Lark. Molecular characterization of the genes encoding acetoacetylcoenzyme A transferase from Serratia marcescens KCTC 2172. Journal of Microbiology and Biotechnology, 2001, vol. 11, no. 5, p. 870-875. 


\section{APPENDIX}

\section{FIGURES}

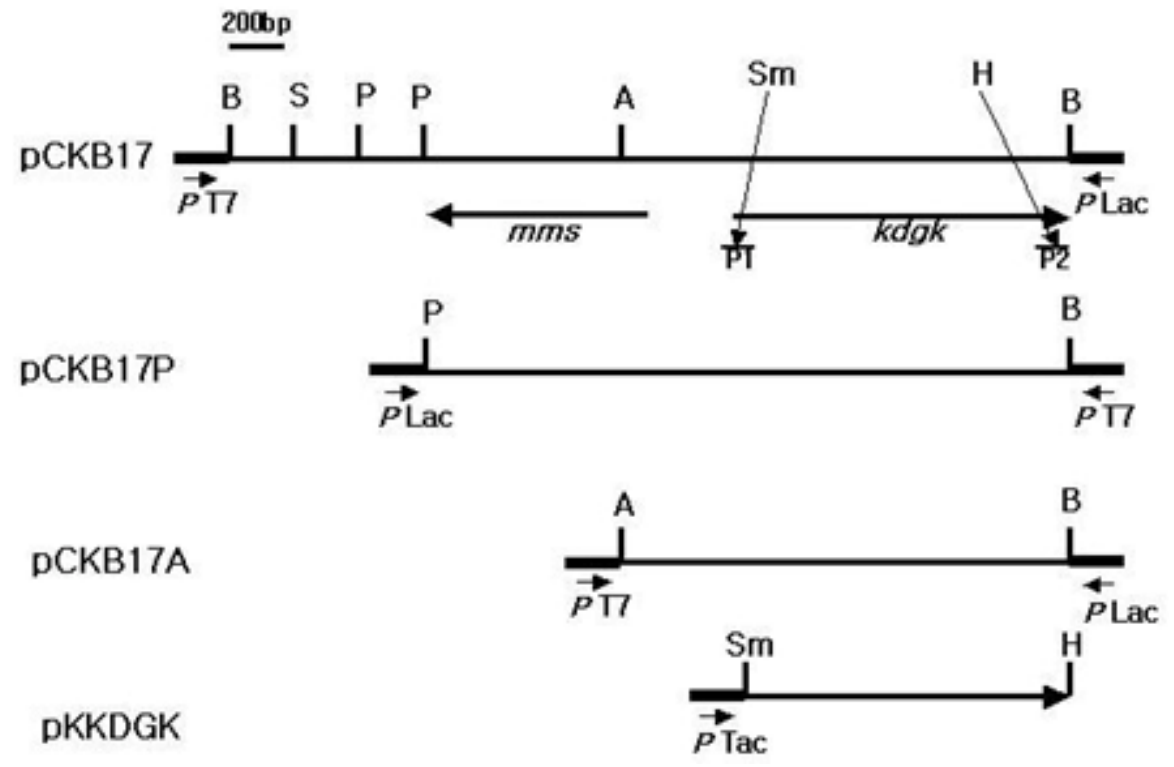

Figure 1. Restriction map of the plasmid pCKB17 from S. marcescens and derivative plasmids. The transcriptional directions of mms and KDGK genes are shown by the thick arrows. (A), Aval; (B), BamHI; (H) HindII; (M), Mlul; (P), Pvull; (S), Sall; (Sm), Smal. 


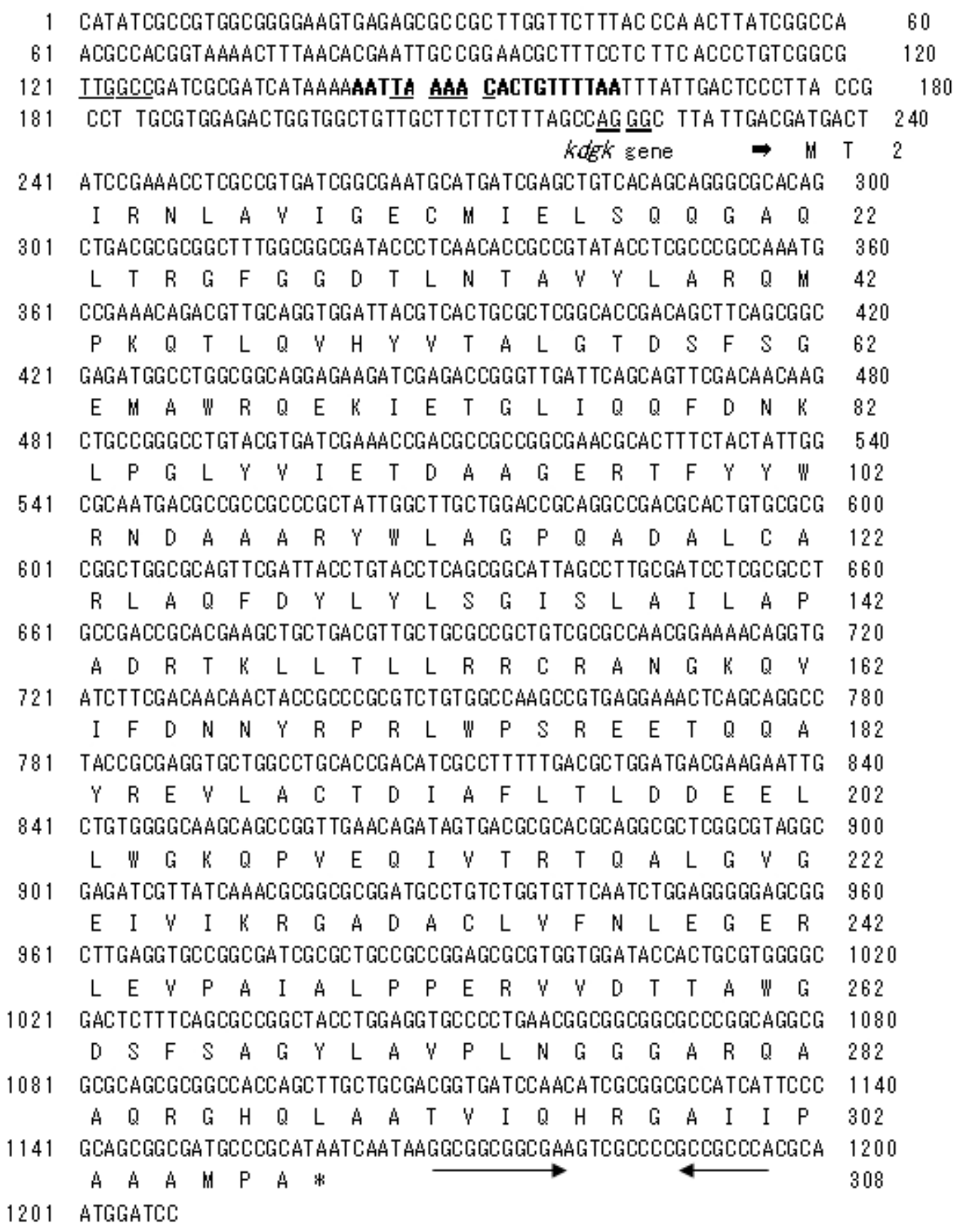

Figure 2. Nucleotide sequence of the $k d g K$ gene from S. marcescens. The predicted amino acid sequences of the coding regions are shown. The underline is indicated putative promoter sequence, bold-underline is putative ribosome binding site and boldface letters indicate KdgR binding site. The horizontal arrow indicates the regions corresponding to inverted repeat sequence. The nucleotide sequence has been assigned GenBank accession number DQ191959. 
(a) ATGAAA----TTTCAT

(b) AAAAAAAGAAAC $(2-4)$ TGTTTCATTATAT $\begin{array}{llll}T & T & T & T T\end{array}$

(c) AAATAATGAAATGGCATTTCATTTTTTT

(d) AATGAAAC--TGTTTCA

A $\quad$ T $C A \quad T$

\section{$k d g K$ AAATTAAAACACTGTTTTAA}

Figure 3. Alignment of the KDGK operator with the consensus of the KdgR binding site. Consensus pattern (a) was established by comparison of the pelE, ogl and $k d g T$ regulatory regions (Reverchon et al. 1989); (b) was established by comparison of 14 putative KdgR binding sites (Condemine et al. 1991); (c) was obtained by comparison of the five pel genes (Hugovieux-Cotte-Pattat et al. 1989), and (d) was deduced from interference experiments conducted with the pelE and ogl operators to define the nucleotides in direct interaction with the KdgR protein (Nasser et al. 1994). The underline indicates conserved nucleotides of KdgR binding site.
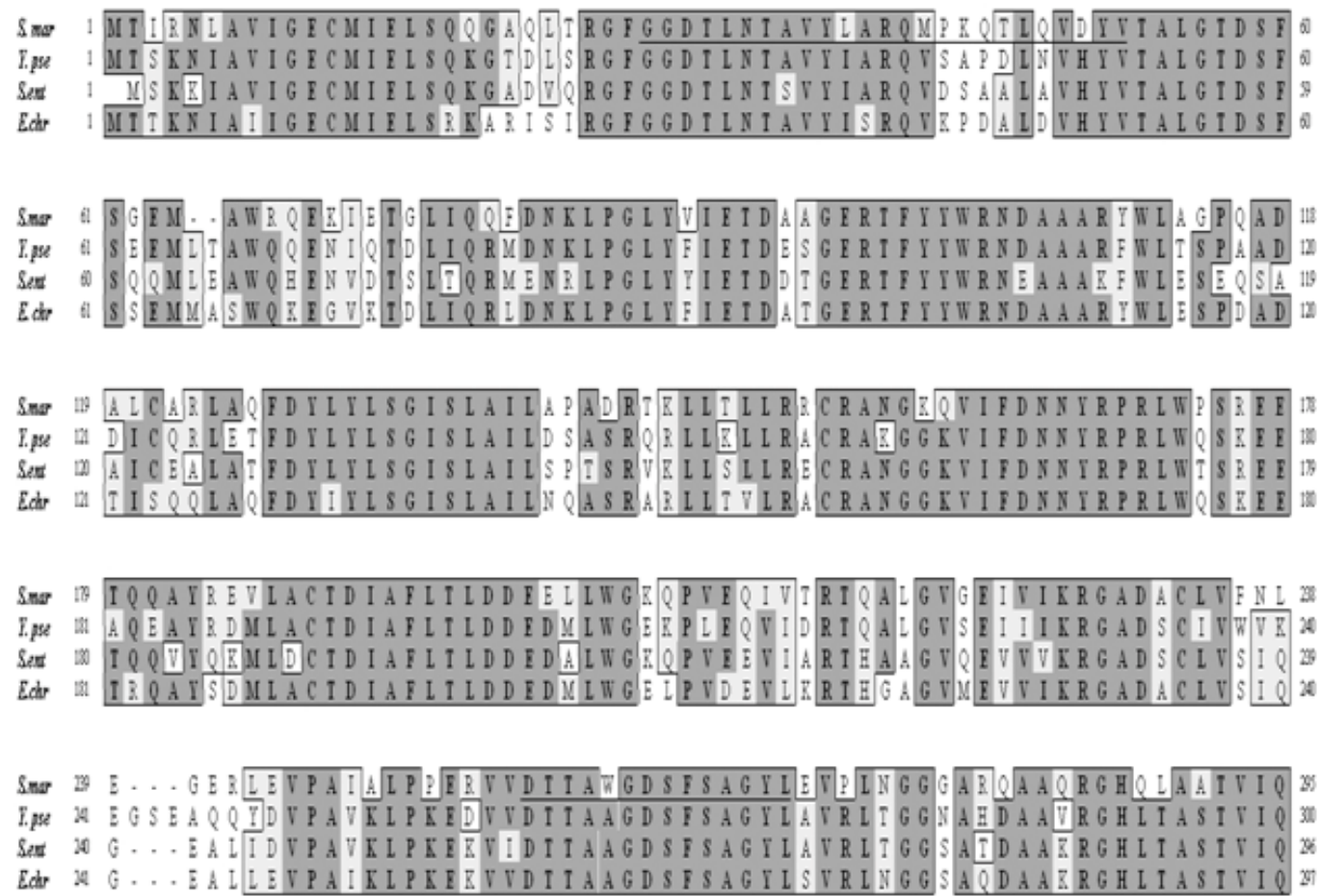

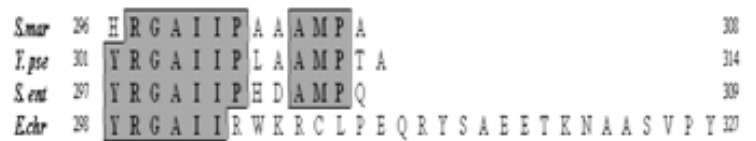

Figure 4. Comparison of the amino acid sequence of the Serratia marcescens KDG kinase with related other KDG kinase sequences. S. mar: Serratia marcescens KCTC 2172; Y. pse: Yersinia pseudotuberculosis (YP_072311); E. chr: Erwinia chrysanthemi (C55215); S. ent: Salmonella enterica (YP_152589. The underline regions are corresponding to the consensus pattern of carbohydrate kinase of the PfkB family. 
Lee, Y. et al.

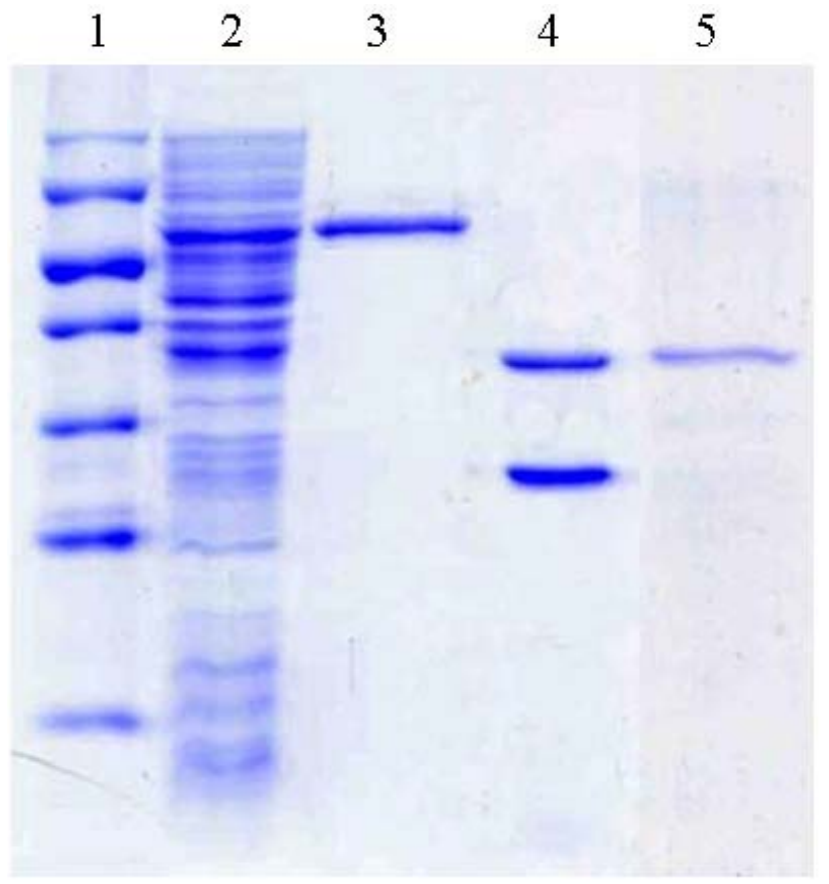

Figure 5. SDS-PAGE patterns obtained with protein preparations at each step of the purification of KDG kinase protein from E. coli. Lane 1, size marker; lane 2, crude extract; lane 3, GST-KDGK; lane 4, GST and KDGK digested with protease; lane 5, Purified KDGK.

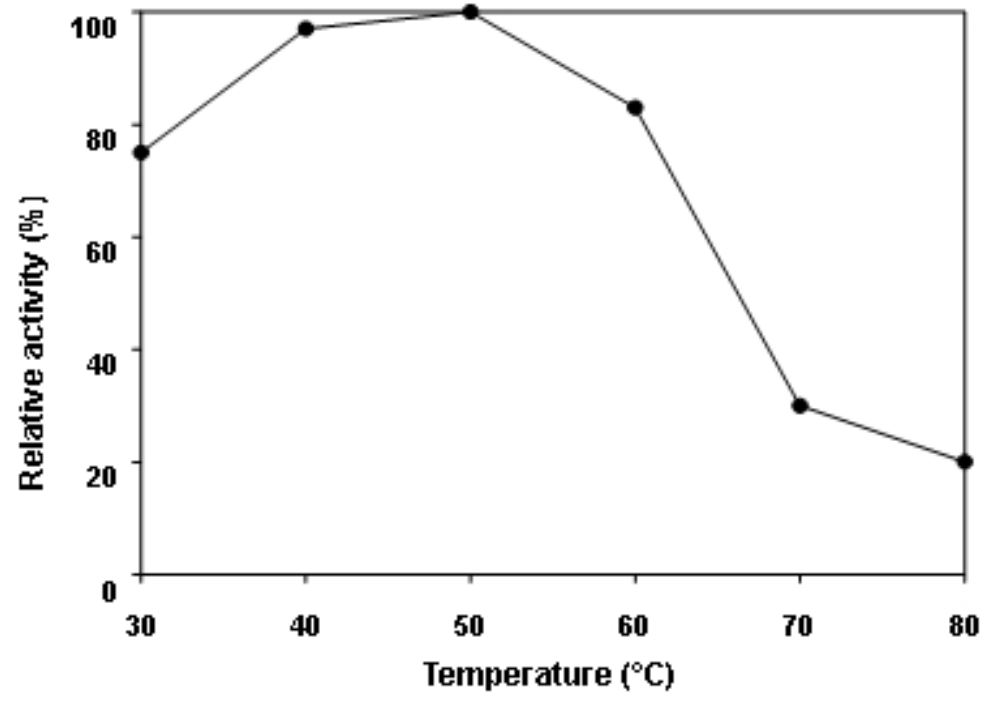

Figure 6. Effect of temperature on KDG kinase activity. 


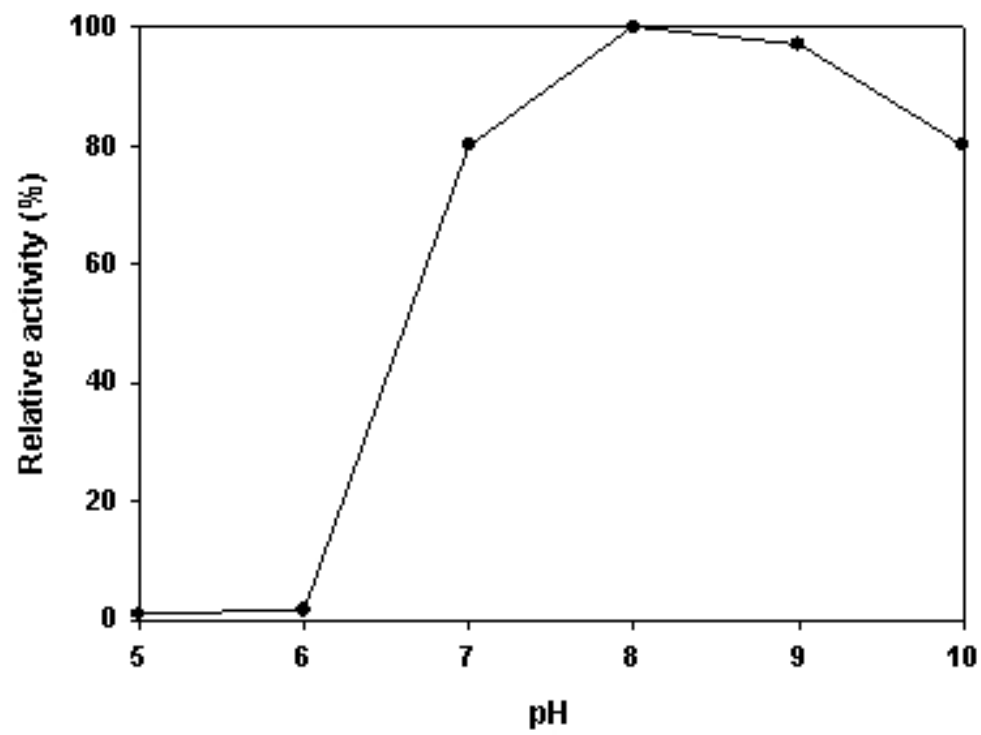

Figure 7. Effect of pH on KDG kinase activity. 